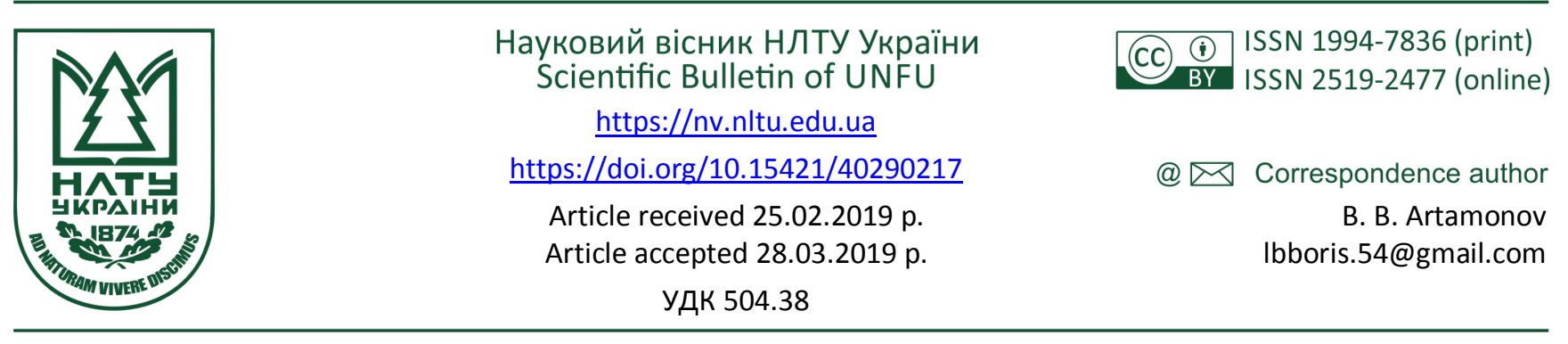

Б. Б. Артамонов, С. М. Шевченко, А. О. Дячук

Хмельницький національний університет, м. Хмельницький, Украйна

\title{
ПРОГНОЗ ВПЛИВУ КЛІМАТИЧНИХ ЗМІН У ХМЕЛЬНИЦЬКІЙ ОБЛАСТІ НА НАВКОЛИШНЄ СЕРЕДОВИЩЕ І НАСЕЛЕННЯ
}

На підставі проведених досліджень з урахуванням кліматичних змін, що зараз відбуваються в усьому світі, визначено особливості цього впливу на територію Хмельницької області. Конкретне визначення й урахування на регіональному рівні параметрів метеорологічних елементів дасть змогу більш уважно ставитись до кліматичних змін, що відбуваються, та приймати обгрунтовані рішення щодо охорони навколишнього природного середовища та убезпечення життєдіяльності мешканців. Для визначення прогнозу кліматичних змін на території області використано архівні дані метеорологічних станцій, що визначають стан погоди на території області, за параметрами температури (середньорічної, максимальної та мінімальної) та кількість опадів за саме такими значеннями з 2005 по 2017 рр. Це дало нам змогу визначити тренд кліматичних змін за середньорічними значеннями температури та кількості опадів на період до 2025 р. Вірогідність зробленого прогнозу перевірено за метеорологічними показниками середньорічної температури та кількістю опадів за 2018 р., що підтвердило правильність нашого прогнозу. На підставі цього було визначено вплив зміни цих метеоелементів на навколишнє середовище і населення області та надано відповідні рекомендації щодо їх врахування. Доцільним, на наш погляд, є їх урахування як органами влади, керівниками установ під час прийняття відповідних рішень, так і мешканцями області, стан здоров'я яких залежить від відповідних метеорологічних змін.

Ключові слова: температура; кількість опадів; стихійні метеорологічні явища; потенційні негативні наслідки зміни клімату.

Вступ. Зміна клімату має великий вплив на життєдіяльність населення та навколишнє середовище в усьому світі. Не є винятком і Хмельницька обл. Але досі вплив кліматичних змін для Хмельницької обл. докладно не розглянуто, тим більше не зроблено прогноз таких змін. У 2015 р. було проведено дослідження стосовно оцінки вразливості та заходів 3 адаптації до зміни клімату м. Хмельницького (Shevchenko \& Vlasiuk, 2015), але ця робота за своїм спрямуванням не може визначити дійсний стан всієї Хмельницької обл., Окрім цього, використання для оцінки вразливості певної визначеної авторами категорії експертів не дає, на наш погляд, повністю вірогідних результатів.

У роботі, на підставі аналізу змін середньорічної температури атмосферного повітря та кількості опадів, було опрацьовано прогноз кліматичних змін для Хмельницької обл. та визначено його вплив на навколишнє середовище і населення. Це дало змогу надати деякі рекомендації стосовно адаптації на такі зміни.

Мета роботи - статистичне оцінювання часового та просторового розподілів фактичних та прогностичних кліматичних показників для встановлення тенденцій та швидкостей змін клімату в Хмельницької обл., а також ступеня мінливості деяких метеорологічних елементів.

Завдання дослідження полягало в розробленні прогнозу кліматичних змін області на період до 2025 р. та визначенні чинників, що будуть мати найбільший негативний вплив на навколишнє середовище та населення.

Матеріали та методи дослідження. Матеріалами для опрацювання цієї роботи були архівні дані метеорологічних станцій, що обслуговують Хмельницьку обл. 3 використанням методів спостереження, аналізу, синтезу, абстрагування та моделювання.

Результати дослідження та їх обговорення. Клімат Хмельницької обл. сформувався під впливом різноманітних чинників, головним з яких є географічна широта, з якою пов'язана висота Сонця над горизонтом і величина сонячної радіації (Ekolohichnyi pasport oblasti, 2017).

Завдяки великій протяжності області з півночі на південь, на іiї території існує декілька природно-кліматичних зон, що зменшує ризики суцільного впливу погодних чинників на сільське господарство по всій території області. Умовно в межах області спостерігаємо три таких зони: Південна - Кам'янець-Подільський та Новоушицький райони, Північна - Славутський, Шепе-

\section{Інформація про авторів:}

Артамонов Борис Борисович, канд. військових наук, доцент, кафедра екології. Email: Ibboris.54@gmail.com; https://orcid.org/0000-0001-7108-748X

Шевченко Сергій Миколайович, канд. с.-г. наук, доцент, кафедра екологіï. Email: sheva911@ukr.net; https://orcid.org/0000-0001-7558-255X

Дячук Андрій Олександрович, канд. пед. наук, доцент, кафедра екологіï. Email: dyachuk_ao@ukr.net; https://orcid.org/0000-0002-5974-7286

Цитування за ДСтУ: Артамонов Б. Б., Шевченко С. М., Дячук А. О. Прогноз впливу кліматичних змін у Хмельницькій області на навколишнє середовище і населення. Науковий вісник НЛтУ України. 2019, т. 29, № 2. С. 88-90.

Citation APA: Artamonov, B. B., Shevchenko, S. N., \& Diachuk, A. O. (2019). Forecast on the influence of climate change in Khmelnytskyi region on the environment and population. Scientific Bulletin of UNFU, 29(2), 88-90. https://doi.org/10.15421/40290217 
тівський, Полонський райони, Центральна - решта районів області (Klimat oblasti, 2019). Це зумовлює деякі відмінності у середньорічних, максимальних та мінімальних температур для відповідних зон (таблиця) (Pohoda oblasti, 2019).

Таблиця. Середні, мінімальні та максимальні значення температури повітря $\left({ }^{\circ} \mathrm{C}\right)$ на висоті 2 м над поверхнею землі за даними 2017 р. для зон Хмельницької області

\begin{tabular}{|c|c|c|c|}
\hline $\begin{array}{c}\text { Зона } \\
\text { області }\end{array}$ & $\begin{array}{c}\text { Середнє } \\
\text { значення }\end{array}$ & $\begin{array}{c}\text { Мінімальне зна- } \\
\text { чення (дата) }\end{array}$ & $\begin{array}{c}\text { Максимальне } \\
\text { значення (дата) }\end{array}$ \\
\hline Північна & $+8,8$ & $-20,4(10.02 .2017)$ & $+34,6(02.08 .2017)$ \\
\hline Центральна & $+8,8$ & $-19,6(07.01 .2017)$ & $+33,5(02.08 .2017)$ \\
\hline Південна & $+10,4$ & $-16,8(10.02 .2017)$ & $+33,9(04.08 .2017)$ \\
\hline
\end{tabular}

Проведені дослідження щодо визначення кліматичних змін за температурою повітря та кількістю опадів у Хмельницькій обл. 32005 по 2017 рр. дали змогу визначити вірогідний прогноз таких змін до 2025 р. (рис. 1, 2) (Pohoda oblasti, 2019).

За результатами проведеного аналізу зроблено висновок, що до 2025 р. на території Хмельницької обл. середньорічні показники температури істотно не зміняться, але можливе невелике їх зниження, а середньорічна кількість опадів може істотно зменшитися. При цьому тенденція щодо різких стрибків показників температури збережеться та може й ще поширитися, а кількість опадів може ще зменшитися. Вірогідність свого прогнозу перевірили за результатами спостережень показників середньорічних значень за 2018 р., що загалом підтвердило наш прогноз кліматичних змін (відповідно точка 1 на рис. 1 та точка 2 на рис. 2).

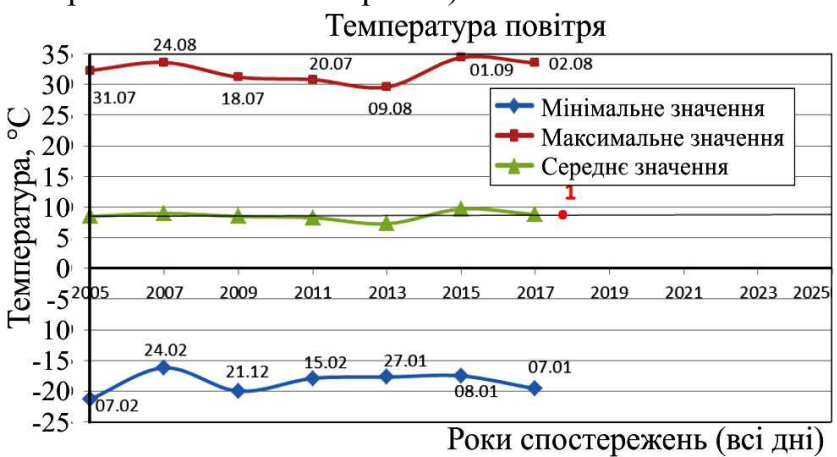

Рис. 1. Аналіз зміни середньорічної температури повітря у Хмельницькій області та їі максимальних та мінімальних значень (2005-2017 pp.): 1) середньорічна температура за 2018 р. $\left(+8,9^{\circ} \mathrm{C}\right)$

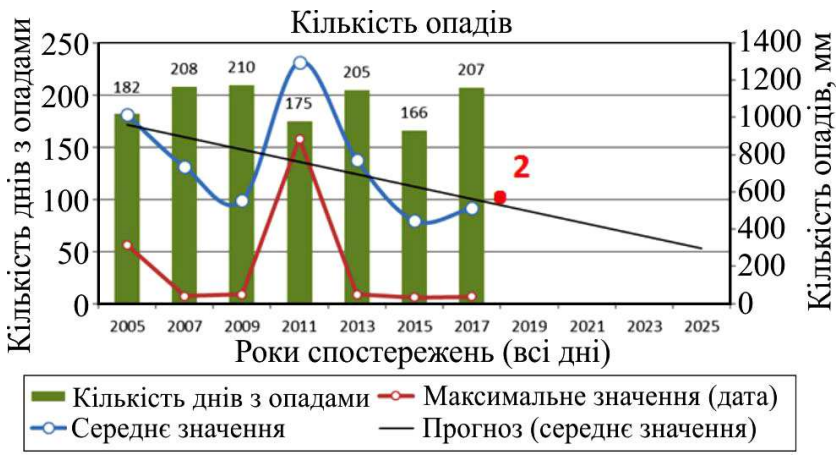

Рис. 2. Аналіз зміни середньорічної кількості опадів у Хмельницькій області та їх максимальних та мінімальних значень (2005-2017 pp.): 2) середньорічна кількість опадів за 2018 р. (577 мм, число днів з опадами - 196)

3 проведених досліджень можна зробити висновок, що до 2025 р. найнебезпечнішими проявами зміни клі- мату у Хмельницькій обл. будуть стихійні метеорологічні явища (СМЯ) (рис. 3) (Prostorovyi analiz, 2013).

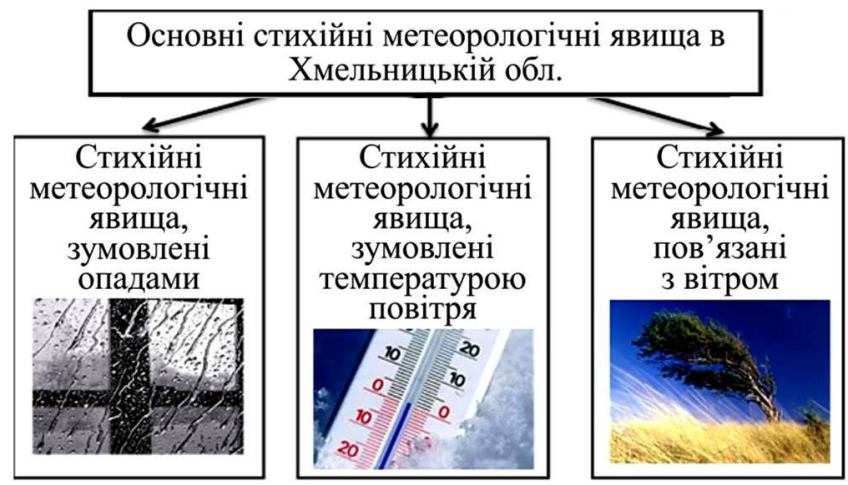

Рис. 3. Основні стихійні метеорологічні явища в Хмельницький області

За останні роки, внаслідок кліматичних змін, їхня кількість в області збільшилась і в багатьох випадках вони мають катастрофічний характер і завдають значних збитків економіці області та навіть призводять до людських жертв. При цьому відзначаємо збільшення кількості випадків дуже сильного дощу та сильного вітру (рис. 4) (Stan seredovyshcha, 2017). Тобто підтверджуємо наявність динаміки СМЯ як загальної закономірності, зумовленої особливостями змін клімату.
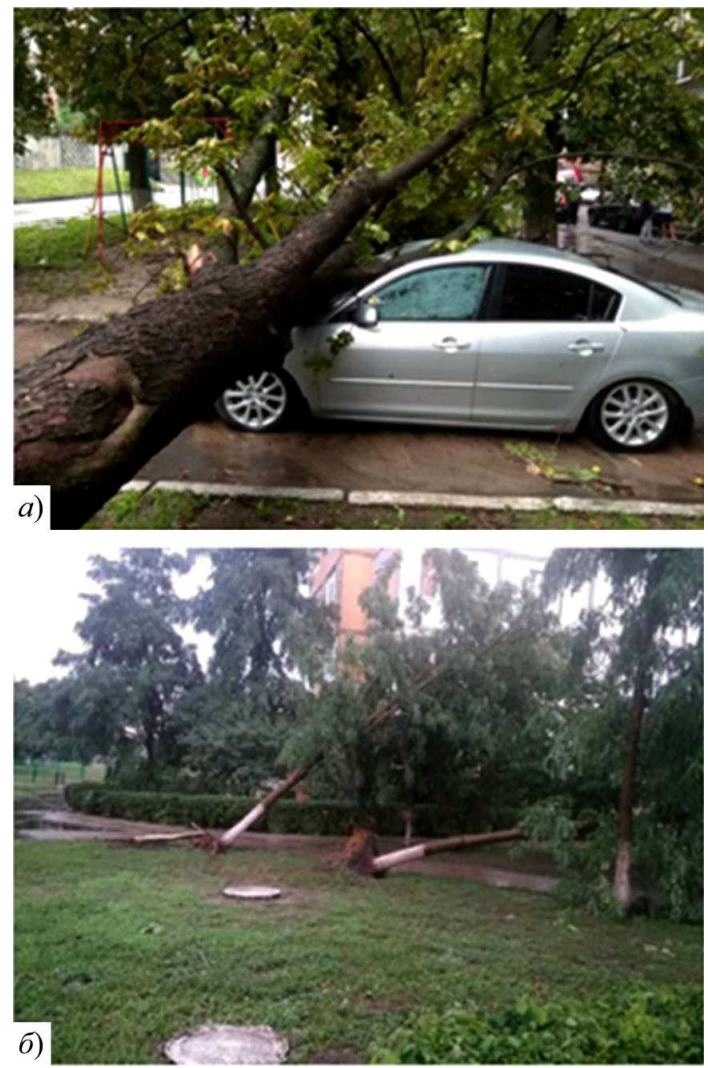

Рис. 4. Наслідки буревію (дощ та поривчастий вітер) на Хмельниччині 30 липня 2018 р. упродовж 30 хв

Отже, на наш погляд, найближчими роками головними проявами кліматичних змін у Хмельницькій обл. будуть:

• короткочасне значне підвищення (зниження) температури повітря;

- зміна термічного режиму;

- зміна структури і кількості опадів;

- збільшення кількості стихійних метеорологічних явищ i екстремальних погодних умов. 
При цьому у холодний період в області відзначаємо тенденцію до збільшення тривалості теплого періоду. Він починається навесні від 15 до 20 днів раніше і закінчується восени від 1 до 6 днів пізніше. Це може зумовити раннє відновлення вегетації рослин, але 3 огляду на це існує вірогідність, що на посіви з ранніми термінами сівби можуть згубно впливати пізні весняні заморозки (Adaptatsiia do klimatu, 2015).

Вплив погоди на людський організм багатогранний i до кінця ще не визначено, але, на жаль, майже 70 \% людей на сьогодні реагують на зміни погоди (Meteozalezhnist, 2017). Метеочутливість вже з'являється навіть у здорових людей. Найбільш ії поширеними симптомами є: сонливість, головний біль, слабкість, запаморочення, неуважність, озноб, прискорене серцебиття. Особливо небезпечними для метеозалежних категорій населення є різкі стрибки метеоелементів. Окрім цього, зміни клімату можуть впливати на схильність до специфічних захворювань. Це переважно інфекційні захворювання, що передаються через воду і комах.

Висновки. До основних потенційних негативних наслідків зміни клімату, що можуть проявлятися у Хмельницькій обл., на наш погляд, належать: посуха; підтоплення та затоплення на півдні області; зменшення площ та порушення видового складу зелених зон; стихійні гідрометеорологічні явища; зниження рівня грунтових вод; зменшення їх кількості та погіршення якості питної води; зростання кількості інфекційних захворювань та алергійних проявів.

Загалом, це може призвести надалі до збільшення негативного впливу на стан навколишнього природного середовища та мешканців Хмельницької обл. Але кліматичні умови на всій території області є придатними для життєдіяльності людей, вживання рекреаційних заходів, вирощування різноманітних сільськогосподарських культур, насамперед озимої і ярої пшениці, ячменю, жита, вівса, цукрових буряків, картоплі, овочевих і кормових культур, плодових дерев. Окрім цього, пів-

денна частина області придатна для виноградарства та баштанництва.

Найближчими роками, через вигідне географічне положення та кліматичні умови, Хмельницька обл., на відміну від деяких регіонів України, за нашими прогнозами, з урахуванням кількості стихійних метеорологічних явищ та змін кліматичних умов, залишиться однією 3 найкомфортніших зон країни.

\section{Перелік використаних джерел}

Adaptatsiia do zminy klimatu. (2015). Ahentstvo spryiannia stalomu rozvytku Karpatskoho rehionu "FORZA".. Retrieved from: http://www.forza.org.ua/sites/default/files/adaptation_climate chan ge brochure ua screen final.pdf. (date of treatment: 13.02.2019). [In Ukrainian].

Ekolohichnyi pasport. (2017). Ekolohichnyi pasport KHmelnytskoi oblasti. Retrieved from: http://www.adm-km.gov.ua/wpcontent/uploads/2017 (date of treatment: 15.01.2019). [In Ukrainian].

Klimat oblasti. (2019). Klimat KHmelnytskoi oblasti. Retrieved from: http://ukr-tur.narod.ru/turizm/regionukr/hmel/klimhmel/ klimhelobl.htm (date of treatment: 6.01.2019). [In Ukrainian].

Meteozalezhnist. (2017). Meteozalezhnist: chomu my reahuiemo na zminy pohody $i$ yak $z$ tsym borotysia. Retrieved from: https://espreso.tv/article/2017/03/01/meteozalezhnist chomu my $\mathrm{r}$ eaguyemo na zminy pogody i yak $\mathrm{z}$ cym borotysya (date of treatment: 13.02.2019). [In Ukrainian].

Pohoda oblasti. (2019). Pohoda v KHmelnytskyi oblasti. Retrieved from: http://rp5.ua (date of treatment: 10.01.2019). [In Ukrainian].

Prostorovyi analiz. (2013). Provedennia prostorovoho analizu tendentsii zminy chastoty ta intensyvnosti ekstremalnykh hidrometeorolohichnykh yavyshch na terytorii Ukrainy vnaslidok zminy klimatu: zvit pro NDR. Derzhavne ahentstvo ekolohichnykh investytsii Ukrainy. Retrieved from: https://uhmi.org.ua/project/rvndr/e xtrime.pdf (date of treatment: 20.01.2019). [In Ukrainian].

Shevchenko, O. H., \& Vlasiuk, O. ya. (2015). Otsinka vrazlyvosti ta zakhody $z$ adaptatsii do zminy klimatu. KHmelnytskyi. Kyiv. Retrieved from: http://climategroup.org.ua/wpcontent/uploads/2015/02/ad_Khmelnitskiy_City_A4.pdf. (date of treatment: 15.12.2018). [In Ukrainian].

Stan seredovyshcha. (2017). Stan navkolyshnoho pryrodnoho seredovyshcha $v$ KHmelnytskii oblasti. Retrieved from: http://www.adm-km.gov.ua/wp-content/uploads/2017/1.pdf (date of treatment: 25.01.2019). [In Ukrainian].

B. B. Artamonov, S. N. Shevchenko, A. O. Diachuk Khmelnytsky National University, Khmelnytskyi, Ukraine

\section{FORECAST ON THE INFLUENCE OF CLIMATE CHANGE IN KHMELNYTSKYI REGION} ON THE ENVIRONMENT AND POPULATION

On the basis of accounting the climate changes in the world, an analysis of changes in the temperature of atmospheric air and rainfall has been carried out and the forecast of climate change in the territory of Khmelnytskyi region (Ukraine) by 2025 has been made. For the analysis of changes in meteorological elements, archival data of meteorological stations of Khmelnytskyi region have been used, namely: the meaning of annual, maximum and minimum temperature of the average annual rainfall, taking into account the number of days with precipitation. The use of obtained data allowed us to determine the trend of climatic changes in the average annual temperature and average annual precipitation for Khmelnytskyi region for the period up to 2025 . In order to verify the reliability of the calculations, the average annual temperature and rainfall data for 2018 have been used, which, in general, confirmed our forecast for the territory of Khmelnytskyi region by 2025 . Based on this, it was concluded that the average annual temperature data will not change significantly in the region by 2025 , but a slight decrease may be possible, and the average annual rainfall can decrease significantly. At the same time, the trend for sharp changes in temperature indicators will continue and may still spread, and the amount of precipitation can still decrease. In addition, climatic changes in the north and south of the region, which are slightly different from those of the center of the region, require more careful consideration. In our opinion, the main manifestations of climate change in Khmelnytskyi region in the period under study will be: short-term significant increase (decrease) in air temperature; change of thermal regime; change in the structure and amount of precipitation; increase in the number of natural meteorological phenomena and extreme weather conditions. The use of the developed climate change forecast in Khmelnytskyi region will allow government officials, heads of relevant institutions and authorities to make informed management decisions, and meteorically dependent residents of the region to monitor their health more closely.

Keywords: temperature; amount of precipitation; spontaneous meteorological phenomena; potential negative impacts of climate change. 